\section{Nauplius}

The Journal of The

Brazilian Crustacean Society

e-ISSN 2358-2936

www.scielo.br/nau www.crustacea.org.br
This article is part of the special series offered by the Brazilian Crustacean Society in honor to Ludwig Buckup in recognition of his dedication and contributions to the development of Carcinology

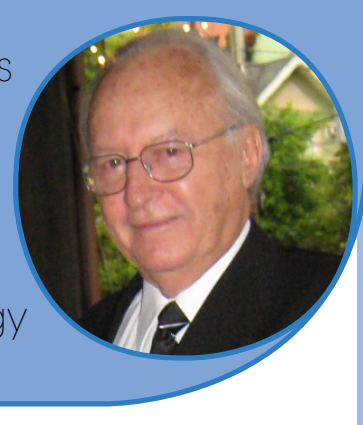

Original Article

\title{
Aegla chilota, new species of anomuran freshwater crab from Chiloé Island, western Patagonia
}

Carlos G. Jara ${ }^{1} \quad$ orcid.org/0000-0001-5337-7985

Marcos Pérez-Losada ${ }^{2,3,4}$ orcid.org/0000-0002-2585-4657

Keith A. Crandall ${ }^{2,3}$ orcid.org/0000-0002-0836-3389

1 Instituto de Ciencias Marinas y Limnológicas, Universidad Austral de Chile. Valdivia, Chile.

CGJ Email: cjarasenn@gmail.com

2 Computational Biology Institute, Milken Institute School of Public Health, The George Washington University. Washington, D.C., 20052-0066, USA. MP-LEmail: mlosada323@gmail.com KAC Email: kcrandall@gwu.edu

3 Department of Invertebrate Zoology, US National Museum of Natural History, Smithsonian Institution. Washington, D.C., 20013, USA.

4 CIBIO-InBIO, Centro de Investigação em Biodiversidade e Recursos Genéticos, Universidade do Porto, Campus Agrário de Vairão. Porto, Portugal.

ZOOBANK: http://zoobank.org/urn:lsid:zoobank.org:pub:17A6984C-BA1F-41859B61-8FE7E5D12886

\section{ABSTRACT}

We describe a new species of freshwater crab, Aegla chilota, from two small streams at Yaldad Bay, in the southern end of Chiloé Island, western Patagonia. The new taxon is distinguished from the remaining Chilean species of Aegla Leach, 1820 by the following morphological diagnostic features: rostrum neatly triangular, short, scarcely surpassing eyes; orbital sinus wide, shallow, limited by tiny extra-orbital spine and wide extra-orbital sinus; carpal lobe prominent, triangular, tipped by at least two coalescent acute conical scales; second abdominal epimeron little produced, armed with acute scale; telson plate roughly pentagonal, with functional median suture. Molecular phylogenetic analyses also support the separation and diagnosis of A. chilota from its sister taxon, A. hueicollensis Jara and Palacios, 1999. The type locality for A. chilota n. sp. is a small river that drains a small hilly 
portion of the south-eastern coast of Chiloé Island; the other river in which the species was found is isolated from the type locality by the Yaldad Bay into which both rivers drain.

KEY WORDS

Aeglidae, Chile, Crustacea, South America, taxonomy

\section{INTRODUCTION}

The genus Aegla Leach, 1820 (Crustacea: Decapoda: Anomura) currently includes 85 species and subspecies (Moraes et al., 2016; Santos et al., 2017; WoRMS, 2018). It is distributed along and across the southern cone of South America, comprising Brazil, Bolivia, Paraguay, Uruguay, Argentina, and Chile. In spite of that wide geographical range and the diversity of environmental conditions encompassed by it, the morphology of aeglid crabs is surprisingly uniform, resulting in a rather restricted suite of morphological characters useful for species identification. Phenetic similarity among nominal species of freshwater crabs of Aegla is not always positively correlated with genetic relatedness. Cryptic species are more common than intuitively accepted by taxonomists. However, geographical exploration coupled with molecular assays provides a basis for recognizing as new species populations in certain areas which otherwise are almost indistinguishable from species previously known. In fact, the combination of molecular tools and morphological evidence has already led to the separation of Aegla occidentalis Jara, Pérez-Losada and Crandall, 2003 in Chile from A. araucaniensis Jara, 1980, to which it closely resembles (Jara et al., 2003). A survey conducted in March 2006 in the Incopulli River (Yaldad Bay, near the southern end of Chiloe Island) to collect Aegla alacalufi Jara and López, 1981, led to the collection of a population of crabs which lacked the most evident diagnostic character of $A$. alacalufi, i.e., telson plate longitudinally undivided. This population was then preliminary assigned to A. araucaniensis due to its morphological similarity. However, subsequent molecular analysis carried out by Xu et al. (2009) showed instead that the Incopulli River aeglids were genetically different from $A$. araucaniensis. In this article, we describe the crabs found in Incopulli
River, Yaldad Bay, as a new nominal species and discuss its evolutionary relationships and conservation status.

\section{Methods}

Population sampling. Specimens of Aegla chilota n. sp. were collected by towing a sack-like net $0.8 \mathrm{~m}$ wide, $0.5 \mathrm{~m}$ high at mouth, and $1 \mathrm{~m}$ long, $500 \mu \mathrm{mesh}$ size, counter current over gravel and boulders on river bottom. Specimens were preserved in $96 \%$ commercial ethanol.

Deposition of type specimens. Holotype, allotype and paratypes were deposited at the National Museum of Natural History (Santiago, Chile) under catalog numbers with prefix MNHNCL DEC.

Morphometrics. Morphometric descriptors were taken from Jara (1982) and Bond-Buckup and Buckup (1994). Measurements were made with a digital caliper to the nearest decimal fraction of $\mathrm{mm}$. Differences in morphometric features were assessed using the Student's t-test for independent samples.

Molecular analysis. Sequences available in GenBank for the mtDNA genes cytochrome oxidase (CO) I (up to $1292 \mathrm{bp}$ ), COII (568 bp) and 16S rRNA (466 bp) from 15 specimens of $A$. chilota (Aegla sp. JX-2009) were combined with sequences from 47 representatives of all of the 19 Aegla species occurring in Chile (see Fig. 1). Nucleotide sequences from each gene region were aligned using MAFFT v6 (Katoh, 2008) under the global (G-INS-i) algorithm and default settings. No ambiguous regions were observed in the alignment. All gene regions were analyzed as separate partitions under the best-fit model of evolution selected by JModelTest v1.0.1 (Posada, 2009). The general time reversible model of evolution, with proportion of invariable sites and gamma distribution was selected for each data partition $(\mathrm{GTR}+\Gamma+\mathrm{I})$. Maximum likelihood analysis of 
Figure 1. Maximum likelihood phylogenetic tree of Aegla from Chile. Branch lengths are shown proportional to the amount of change along the branches. Bootstrap proportions (if $\geq 70 \%$ ) are indicated for main internal nodes. 
the concatenated partitions was performed in RAxML v7.2.0 (Stamatakis et al., 2008) using 1,000 searches and 100 runs. Clade support was assessed using the non-parametric bootstrap procedure (Felsenstein, 1985 ) with 5,000 bootstrap pseudoreplicates run in the portal CIPRES Science Gateway portal (Miller et al., 2010).

\section{Systematics}

\section{Family Aeglidae Dana, 1852}

\section{Genus Aegla Leach, 1820}

\section{Aegla chilota, new species}

$$
\text { Figure } 2(\mathrm{a}-\mathrm{g})
$$

Diagnosis. Aegla chilota, new species, is distinguished from the remaining species of Chilean Aegla by having the ensuing character combination: rostrum neatly triangular, short, scarcely surpassing eyes; orbital sinus wide, shallow, limited by tiny extra-orbital spine and extra-orbital sinus; carpal lobe prominent, triangular, tipped by at least two coalescent acute conical scales; second abdominal epimeron little produced, tipped by acute scale; telson plate roughly pentagonal, with functional median suture; presence of the rectangular palmar crest.

Type material. Holotype, male $20.3 \mathrm{~mm}$ CL (carapace length), MNHNCL DEC-15104. Allotype, female, $16.8 \mathrm{~mm}$ CL, MNHNCL DEC-15105. Paratypes: two males, (P1M) 16.7, and (P2M) 15.5 mm CL; three females, (P3F) 17.2 (P4F, ovigerous) 15.0 and (P5F) $14.3 \mathrm{~mm}$ CL, respectively, MNHNCL DEC-15106. The type series was collected on November 05, 2008, under a bridge over the Incopulli stream, which finally drains into Yaldad Bay, at 43॰06’02” S; 73041'47” W, $21 \mathrm{~m}$ above sea level, $2 \mathrm{~km}$ to East from Yaldad town, Chiloé Island, Chile (Fig. 3).

Additional material examined. Five males, labeled as M1 to M5, (CL 17, 16.7, 15.8, 15.6, $14.4 \mathrm{~mm}$, respectively), and one female, F1, (CL $14.2 \mathrm{~mm}$ ), MNHNCL DEC-15107, collected on November 06, 2008, from Yeco or Yecuitá stream that drains into

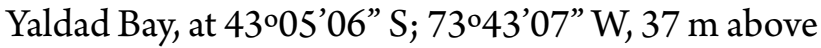
sea level, $2.44 \mathrm{~km}$ straight line NW from type locality.
Description (based on male holotype). Body almond-shaped. Margins of carapace smooth. Rostrum short (CL/RL ratio 6,8), rather flat, neatly triangular, scarcely surpassing eyestalks corneae. Rostral margins with row of tiny acute scales extended between orbital sinus and rostral tip; scales increasing in size toward rostral tip. Rostral carina low, almost merged with rostral body, with diffuse row of scales along its longitudinal axis; close to rear end between epigastric lobes, profile becomes concave. Tip of rostrum with blunt apical scale surrounded by "crown" of smaller scales and very short setae. Both sides of rostral carina with flat, slightly concave area limited by margin of rostrum and epigastric eminence. Epigastric eminences as arquate, low, blunt crest extended between most prominent portion, just behind deepest part of orbit, and fronto-lateral part of gastric area where it fades out. Protogastric lobes inconspicuous. Anterolateral lobe of carapace wide, with prominent acute anterolateral spine separated from orbital sinus by shallow extraorbital notch. Limit between orbital and extraorbital sinus marked by small acute scale mounted on edge of orbital ridge; below it another small scale on margin of orbital wall. Orbital sinus amply wide, not particularly deep. Gastric area wide, markedly convex, somewhat bulbous just behind protogastric lobes; lateral margins clearly delimited from hepatic areas by irregular semicircular crease. Hepatic lobes well defined, blunt margins with row of small conical scales. First hepatic lobe separated from anterolateral lobe of carapace by wide deep indentation.

Branchial areas rather narrow compared with wide expanded cardiac area. Cervical groove moderately incised at limit between gastric and cardiac areas, and between third hepatic lobe and interior branchial area. "Bar" linea, at junction of interior, anterior and posterior branchial areas and cardiac area, diverging from carapace midline in $45^{\circ}$. Cardiac area almost square, little longer than wide, with broad areola and large button-like swellings both sides anterior end of it. Cardiac area as wide as posterior branchial area. Margin of branchial areas smooth, without teeth or spines, only with irregular row of small acute conical scales atop tiny tubercles more marked along anterior branchial margin. Margin of posterior branchial area slightly recurved, as continuation of thick carapace rear end margin. Anterior branchial lobe pyramidal, little 




Figure 2. Aegla chilota n. sp., male holotype, MNHNCL DEC-15104. a, Dorsal view of carapace; b, lateral view of pre-cervical carapace; c, ventral view of proximal segments of left cheliped showing absence of tubercle on ventral face of carpus; $d$, enlarged dorsal view of carpus inner margin of left cheliped showing apical ornamentation of carpal lobe; e, lateral view of second abdominal epimeron; $\mathrm{f}$, sternum of third and fourth thoracic segments; $\mathrm{g}$, telson plate. Scale bar $=5 \mathrm{~mm}$. 


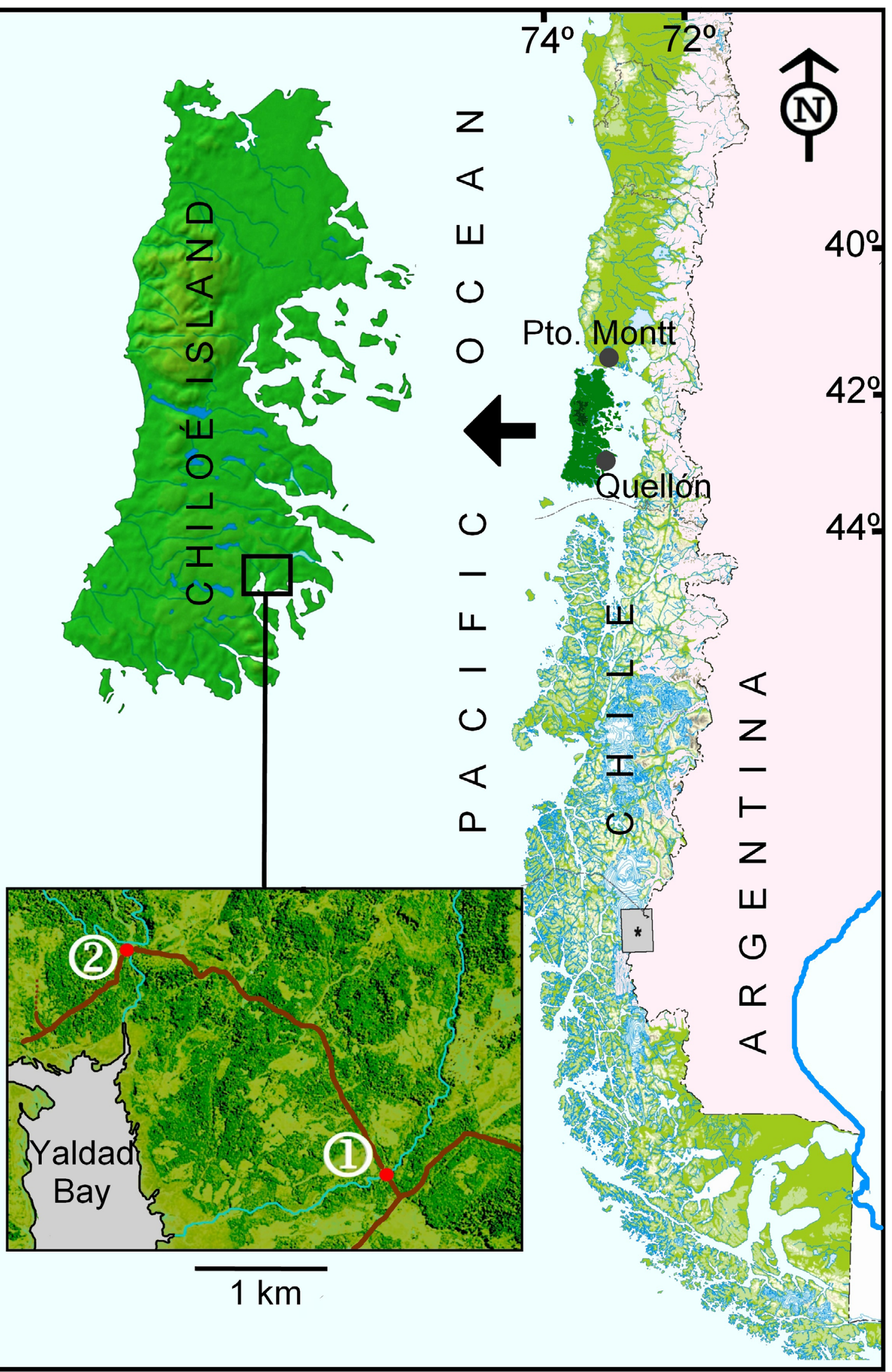

Figure 3. Map of Yaldad Bay showing the type locality of Aegla chilota n. sp. in the Incopulli River (1) and also the Yeco stream (2), from which additional specimens were obtained. 
protuberant; tip does not surpass the level of branchial margin behind it, bearing a conical scale little larger than those along branchial margins.

Abdomen normal, with dorso-latero-external angle of second epimeron produced as conical acute tubercle tipped by conical scale; behind it a blunt lateral ridge that fades out on epimeron rear end; tip of latero-external angle does not surpass level of posterior branchial margin. Ventro-lateral angle of second epimeron (seen from ventral side) blunt, with irregular line of stiff, long setae extending along ventral border to the tip of dorso-latero-external angle; ventral inner margin of same epimeron with dense fringe of long plumose setae. Lateral angle of third and fourth epimera tipped with minute conical scale. Same angle on fifth and sixth epimera blunt, unarmed. Telson plate sub-pentagonal, little wider than long, with functional median suture.

Chelipeds large, moderately massive at propodus of chelae; left larger than right. Coxae without ornamentation. Basi-ischium with blunt tubercle on dorso-external edge; ventro-external border unornamented; ventro-internal margin with three, low crater-like tubercles, each bearing a bunch of stiff long setae; one of them at proximal end; one at the limit between the proximal and the middle third; and, one at the distal end which is the largest; that one on left ischium with minute apical scale. Ventro-internal margin of merus with row of equidistant pits from which bunches of 3 to 5 long, stiff, setae arise. Small acute scale on rear part of two of the pits (right cheliped). Distal end of ventrolateral margin with large conical, acute tubercle. Ventro-external margin smooth; distal end with two small conical tubercles tipped with one small sub-acute scale. Sub-articular tubercle on distal end of same margin with 2 (left), 3 (right cheliped) small scales in a dorso-ventral row. Dorsal margin of ischium rather sharp edged, with row of low tubercles tipped by small conical scales increasing in size from proximal to distal; distal largest. Dorso-distal swelling above ischio-carpal joint little developed, its free border with 7 (left) and 9 (right) minute scales in a row. Carpus not particularly ornamented. Dorso-internal border with 3 large conical spines, tipped with acute scale, in a row increasing in size from proximal to distal. Carpal lobe large but not particularly prominent, summit frontally displaced so that it is aligned with distal border of carpus, close to dorsal carpus-propodus articular knob. Apex of carpal lobe with 3 (left) and 2 (right) large conical scales, flanked by scales of lesser size and minute stiff setae. Frontal margin of carpus with fringe of small, equidistant, conical scales. Dorsum with two tuberculate ridges; larger one arquate, parallel to base of spines of dorso-internal margin, thick, prominent, formed by 7 (left) and 6 (right) knob-like tubercles bearing irregular oblique row of two to six minute rod-like scales; lesser one formed by 3 or 4 low flat tubercles bearing 2 or 3 minute scales and stiff setae, situated on external half of dorsum, proximal to meruscarpus joint. Ventral face of left carpus smooth, only with some scabrosities and long, stiff, simple setae; right carpus with a broad-based conical tubercle tipped by acute, short, scale surrounded by long simple setae. Left propodus larger than right, their surface rough due to minute acute scales pointing frontally. Palmar crest moderately expanded; margin of left one with 3 serrated teeth, margin of right with 4 teeth, tipped by acute scale. Disto-dorsal margin above dactylar joint with row of small scales; upper angle with a scale larger than those in adjacent row. Ventral face with welldefined sub-marginal ridge behind fixed finger; row of pits from which bundles of long simple setae arise; each pit adjacent to small tubercle tipped by scale. Cutting edge of left propodus with large angular tooth at about midpoint. Dactylus regularly curved, dorsal margin near propodus joint with low pyramidal lobe tipped by one or two large conical scales. Distal half of ventral face of dactylus markedly excavate, forming with opposite and equally excavate propodal finger a deep concavity. Distal tip of dactylus at closing border of chela with large canine-like corneous teeth. Cutting edge of left dactylus with moderately thick molar process at proximal end. Pereopods with fringe of plumose setae along dorsal margin of merus; opposite margin with row of acute scales intermingled with short stiff setae; scales on margin's distal end larger and regularly spaced forming a palisade. Margins of remaining articles with band of short, stiff setae mixed with scattered minute scales. Disto-dorsal angle of carpus of second and third pair of pereopods produced as conical tubercle tipped by acute scale. Dactylus as long as propodus, tip with curved acute, long, conical scale; postero-ventral margin, adjacent to tip, with longitudinal row of 6 or 7 acute rod-like scales increasing in size from proximal to 
distal end. Thoracic sterna flat, their surface punctuated by shallow pits bearing 2 or 3 short simple setae.

Allotype. It differs from holotype by having slightly longer rostrum (CL/RL ratio 5.6), with acute apical scale; sub-apical "crown" of short stiff setae and minute scales absent (probably worn out). Gastric area apparently more elevated, summit almost flat, deeply punctate. Antero-lateral angle of second abdominal epimeron less protruding; same angle of third and fourth epimera blunt, without apical scale. Chelipeds slender; homochelic. Tubercles on dorsal border of merus very low, blunt. Inner margin of carpus with only two large spines; ventral face with low, blunt, tubercle; carpal lobe with three apical acute scales of similar size in a row.

Paratypes. No morphological variations with respect to the holotype were observed, except for the absence, in both chelipeds of P3F, of the broad-based conical acute tubercle present on the ventral face of the carpus of the right cheliped of the holotype. Both male paratypes had injuries of unknown origin that left notorious scars. Male P1M has a deep scratch on the upper part of the gastric area, oblique to the longitudinal median line, about $3.8 \mathrm{~mm}$ long; furthermore, the right third maxilliped is completely lacking except its coxa, and from the left maxilliped only remains the exopod. Male P2M lacks the right uropod completely, and the right half of the telson, including the anus orifice; the healing process produced the deformation of the remaining telson plate and the obliteration of its median suture; the anus orifice opens without protection from proctal plate and sphincter, which were destroyed.

Additional material. Diagnostic characters are well expressed in all six specimens except the absence of spine, and the coalescent acute scales on its tip, on the carpal lobe of the right cheliped of M1. Variation is also observed in relation with the broad-based conical acute tubercle that is present on the ventral face of the carpus of the right cheliped of the holotype. Among the additional specimens, that particular conical tubercle is present on the right carpus of $\mathrm{M} 1$ and $\mathrm{M} 4$, on both carpuses of M2, M3, and M5 but absent from both carpuses of F1.

Morphological variation. Examination of the whole sample of $A$. chilota n. sp. collected at Iñipulli stream
(53 specimens) led to find one male ( $9 \mathrm{~mm} \mathrm{CL}$ ) with partially, and one female $(15.8 \mathrm{~mm} \mathrm{CL})$ with completely obliterated telson median suture.

Morphometry. Table 1 summarizes the morphometric data related to the type series specimens. Table 2 summarizes the same measurements for the additionally examined material. No significant morphometric differences (Student's t-test for independent samples) were found when comparing the mean value of $\mathrm{CL} / \mathrm{RL}$, $\mathrm{PCW} / \mathrm{FW}$, and AL/AW ratios of both populations. $A$. chilota $\mathrm{n}$. sp. has short rostrum (CL/RL mean value for type series $5.67 \pm 0.53, \mathrm{n}=6)$, narrow front $(\mathrm{PCW} /$ FW $1.92 \pm 0.14)$, and square areola (AL/AW $1.27 \pm$ 0.05) (see Bond-Buckup and Buckup, 1994).

Biology. The ovigerous female (P4F) had 104 eggs attached to its pleopods, all of them in moderate state of development, equivalent to stage 7 , early zoea, described by Lizardo-Daudt and Bond-Buckup (2003) in A. platensis Schmitt, 1942.

Etymology. Specific epithet, i.e., chilota, from Latin (Spanish), inhabitant of (endemic to) Chiloé Island.

Comparison. Aegla chilota n. sp., at first glance resembles A. alacalufi in having short, neatly triangular, rather flat rostrum, flanked by wide orbital sinus; little pronounced rostral carina; wide, protuberant, gastric area with thick, nodulose, epigastric prominences, and scarcely marked protogastric lobes; epibranchial tooth little protuberant; branchial margins smooth; carpal lobe pyramidal, its apex close to the distal end of carpus; and, palmar crest rectangular, little expanded, its free border denticulate or nodulate. A. chilota differs from A. alacalufi in having an irregular row of tiny scales along the rostral carina; latero-external margin of the antero-lateral lobe of carapace slightly sinuose but not markedly sigmoid; antero-lateral angle of second abdominal epimeron produced, bearing conical sharp scale; telson plate with well-marked median suture; and sternum of fourth thoracic segment flat, without broad, low anteromedial tubercle. A. chilota $\mathrm{n}$. sp. shares with A. hueicollensis Jara and Palacios, 1999 all the latter diagnostic characters, differing from it solely by consistently having the carpal lobe tipped by two to four acuminate scales, a character that sporadically appears in A. hueicollensis. 
Table 1. Morphometry of Aegla chilota n. sp. type series from River Incopulli at 43॰06'02” S; 7341'47” W. Measurements in mm. M= male; $\mathrm{F}=$ female; $\mathrm{F}^{*}=$ ovigerous female; Holo= holotype; Allo = allotype; $\mathrm{P} 1$ to P5 = paratypes. $\mathrm{CL}$, carapace length between rostral apex and posterior margin of cephalothorax; RL, rostral length between rostral tip and transversal line tangent to deepest point of orbits; PCL, precervical length between rostral tip and midpoint of cervical groove; FW, frontal width between tips of anterolateral angles of carapace; PCW, maximum precervical width across third hepatic lobes; CW, maximum carapace width; AL, areola length along carapace dorsal midline; AW, areola maximum width; LCL, left cheliped length; RCL, right cheliped length; L2PL, left second pereiopod length; L2DL, dactylar length of left second pereiopod; L4DL, dactylar length of left fourth pereiopod; TL, telson length.

\begin{tabular}{|c|c|c|c|c|c|c|c|}
\hline & Holo & Allo & P1 & P2 & P3 & P4 & P5 \\
\hline Sex & $\mathrm{M}$ & $\mathrm{F}$ & $\mathrm{M}$ & $\mathrm{M}$ & $\mathrm{F}$ & $\mathrm{F}^{*}$ & $\mathrm{~F}$ \\
\hline CL & 20.3 & 16.8 & 16.7 & 15.5 & 17.2 & 15 & 14.3 \\
\hline RL & 3 & 3 & 3 & 2.8 & 3 & 2.8 & 2.8 \\
\hline PCL & 13.7 & 11.3 & 11.2 & 10.7 & 11.6 & 10 & 9.7 \\
\hline FW & 7.3 & 4.9 & 5.4 & 5.3 & 5.5 & 5 & 4.9 \\
\hline PCW & 12.8 & 10.9 & 10.3 & 9.9 & 10.6 & 9.7 & 8.9 \\
\hline $\mathrm{CW}$ & 17 & 13.8 & 13.8 & 13 & 14.2 & 12.9 & 11.4 \\
\hline $\mathrm{AL}$ & 6.2 & 4.9 & 4.7 & 4 & 5 & 4.3 & 4 \\
\hline AW & 4.8 & 3.8 & 3.9 & 3 & 4 & 3.5 & 3 \\
\hline LCL & 28.2 & 18.7 & 21 & 21 & 19.1 & 18 & 16.6 \\
\hline $\mathrm{RCL}$ & 25.7 & 19 & 22.2 & 19.7 & 18.7 & 17.2 & 16.4 \\
\hline L2PL & 29.6 & & 25 & 22.3 & 23.7 & 19.3 & 19.1 \\
\hline L2DL & 7.2 & & 5.8 & 5.4 & 5.4 & 5 & 4.8 \\
\hline L4DL & 7.6 & 5.5 & 6 & 5.5 & 6 & 5.3 & 4.9 \\
\hline $\mathrm{TL}$ & 4.1 & 4.2 & 3.3 & & 4.1 & 3.9 & 3 \\
\hline $\mathrm{CL} / \mathrm{RL}$ & 6.8 & 5.6 & 5.6 & 5.5 & 5.7 & 5.4 & 5.1 \\
\hline $\mathrm{PCW} / \mathrm{FW}$ & 1.8 & 2.2 & 1.9 & 1.9 & 1.9 & 1.9 & 1.8 \\
\hline $\mathrm{AL} / \mathrm{AW}$ & 1.3 & 1.3 & 1.2 & 1.3 & 1.3 & 1.2 & 1.3 \\
\hline
\end{tabular}

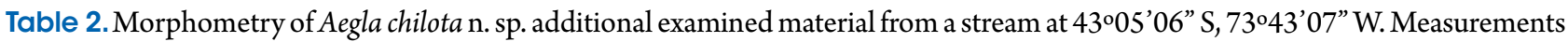
in $\mathrm{mm} . \mathrm{M}=$ male; $\mathrm{F}=$ female. Captions as in Table 1.

\begin{tabular}{|c|c|c|c|c|c|c|}
\hline Sex & M1 & M2 & M3 & M4 & M5 & F1 \\
\hline CL & 17 & 16.7 & 15.6 & 15.8 & 14.4 & 14.2 \\
\hline $\mathrm{RL}$ & 2.9 & 2.8 & 2.7 & 2.9 & 2.2 & 2.5 \\
\hline PCL & 11.1 & 11 & 10.3 & 10.5 & 9.9 & 9.8 \\
\hline FW & 5.8 & 5.7 & 5.3 & 5.2 & 5 & 5 \\
\hline PCW & 10.7 & 10.3 & 9.9 & 9.9 & 9 & 9.1 \\
\hline $\mathrm{CW}$ & 14 & 13.5 & 12.8 & 12.8 & 12 & 11.6 \\
\hline $\mathrm{AL}$ & 4.8 & 4.8 & 4.2 & 4.7 & 4.1 & 4 \\
\hline AW & 4.2 & 3.9 & 3.8 & 3.5 & 3.2 & 3.1 \\
\hline LCL & 20.5 & 21 & 19.3 & 17.5 & 17 & 16 \\
\hline $\mathrm{RCL}$ & 19.8 & 20.2 & 19.3 & 18.5 & 16.7 & 16 \\
\hline L2PL & 23.2 & 23.6 & 23.5 & 22 & 20.3 & 19.2 \\
\hline L2DL & 5.4 & 5.6 & 5.4 & 4.9 & 4.6 & 4.2 \\
\hline L4DL & 5.8 & 5.8 & 6 & 5.1 & 5 & 4.3 \\
\hline $\mathrm{TL}$ & 3.8 & 3.8 & 3.4 & 3.4 & 3 & 3.1 \\
\hline $\mathrm{CL} / \mathrm{RL}$ & 5.9 & 6.0 & 5.8 & 5.4 & 6.5 & 5.7 \\
\hline $\mathrm{PCW} / \mathrm{FW}$ & 1.8 & 1.8 & 1.9 & 1.9 & 1.8 & 1.8 \\
\hline $\mathrm{AL} / \mathrm{AW}$ & 1.1 & 1.2 & 1.1 & 1.3 & 1.3 & 1.3 \\
\hline
\end{tabular}

Systematics. The 15 A. chilota n. sp. specimens formed a clade (Fig. 1) in our maximum likelihood tree sister related to A. hueicollensis ( $\mathrm{bp}=71 \%)$. Both species belong to clade A in Pérez-Losada et al. (2004) together with A. affinis Schmitt, 1942, A. bahamondei Jara, 1982, A. occidentalis, A. alacalufi, A. manni Jara,
1980, and A. denticulate, Nicolet, 1849. It is also interesting to highlight that of all the Aegla species in this clade A, only A. alacalufi and A. denticulata currently occur on the island of Chiloé.

Conservation. Since the taxon is new, a conservation status has not been assigned. However, field 
observations by C. Jara (pers. obs., October 2014) suggest that $A$. chilota n. sp. populations are neither threatened by human activities nor by foreign invasive species such as the American mink Neovison vison. However, the known extent of occurrence (as defined in the IUCN, 2017) is limited and estimated to be $<100 \mathrm{~km}^{2}$; consequently, the conservation status of $A$. chilota can be considered Vulnerable (IUCN, 2017).

Remarks. Obliterated telson median suture is a morphological feature found, as a norm, in two Chilean species, i.e., A. papudo Schmitt, 1942, and A. alacalufi. However, molecular data (Pérez-Losada et al., 2002; 2004) indicate that those two species do not share a recent common ancestor; therefore, the obliterated telson median suture appears as an apomorphic character acquired independently by them. In the case of $A$. chilota n. sp., the cause of the obliteration of the telson median suture in a small fraction of the population is an open question, but it seems relevant to note that $A$. chilota n. sp. resembles $A$. alacalufi, and that its micro-endemic distribution is included in the much wider geographic range of $A$. alacalufi, implying perhaps occasional gene flow between populations of both species.

\section{ACKNOWLEDGEMENTS}

Authors thank Mr. Erwin Barría and Mrs. Patricia Araya for collaborating in field work. This work was funded by a grant from the U.S. National Science Foundation (NSF) PIRE program (OISE 0530267) to support collaborative research on Patagonian Biodiversity among the following institutions (listed alphabetically): Brigham Young University, Provo, Utah, USA; Centro Nacional Patagónico, Puerto Madryn, Chubut, Argentina; Dalhousie University, Halifax, Nova Scotia, Canada; Instituto Botánico Darwinion, Buenos Aires, Argentina; Universidad Austral de Chile, Valdivia, Chile; Universidad de Concepción, Concepción, Chile; Universidad Nacional del Comahue, Centro Regional Universitario Bariloche, Argentina; and George Washington University, Washington DC, USA.

\section{References}

Bond-Buckup, G. and Buckup, L. 1994. A Família Aeglidae (Crustacea, Decapoda, Anomura). Arquivos de Zoologia, São Paulo, 32:159-346.

Dana, J.D. 1852. Crustacea, Part I. p. 475-478. In: United States Exploring Expedition during the years 1838, 1839, 1840, 1841, 1842, under the command of Charles Wilkes, U.S.N.S.I.: s.n., v. 13. Philadelphia, C. Sherman.

Felsenstein, J. 1985. Confidence limits on phylogenies: an approach using the bootstrap. Evolution, 39: 783-791.

Jara, C. 1980. Dos nuevas especies de Aegla Leach (Crustacea, Decapoda, Anomura) del sistema hidrográfico del río Valdivia. Anales del Museo de Valparaíso, 13: 255-266.

Jara, C. 1982. Aegla bahamondei, new species (Crustacea: Decapoda: Anomura) from the Coastal Mountain Range of Nahuelbuta, Chile. Journal of Crustacean Biology, 2:232-238.

Jara, C.G. and López, M.T. 1981. A new species of freshwater crab (Crustacea: Anomura: Aeglidae) from insular south Chile. Proceedings of the Biological Society of Washington, 94: 88-93.

Jara, C.G. and Palacios, V.L. 1999. Two new species of Aegla Leach (Crustacea: Decapoda: Anomura: Aeglidae) from southern Chile. Proceedings of the Biological Society of Washington, 112: 106-119.

Jara, C.G.; Pérez-Losada, M. and Crandall, K.A. 2003. A new species of freshwater anomuran crab of the genus Aegla Leach, 1821 (Crustacea: Decapoda: Aeglidae) from the Nahuelbuta Coastal Range, Chile. Proceedings of the Biological Society of Washington, 116: 933-942.

IUCN 2017. The IUCN Red List of Threatened Species. Version 2017-3. Available at http://www.iucnredlist.org. Accessed on 05 December 2017.

Katoh, T. 2008. Recent developments in the MAFFT multiple sequence alignment program. Briefings in Bioinformatics, 9: 286-298.

Leach, W.E. 1820. Galatéadées. p. 49-56. In: F.G. Levrault (ed), Dictionnaire des Sciences Naturelles. Strasbourg. V.18.

Lizardo-Daudt, H.M. and Bond-Buckup, G. 2003. Morphological aspects of the embryonic development of Aegla platensis (Decapoda, Aeglidae). Crustaceana, 76: 13-25.

Miller, M.A.; Pfeiffer, W. and Schwartz, T. 2010. Creating the CIPRES Science Gateway for inference of large phylogenetic trees. New Orleans, LA, Gateway Computing Environments Workshop (GCE), 8p.

Moraes, J.C.B.; Terossi, M.; Buranelli, R.C.; Tavares, M.; Mantelatto, F.L. and Bueno, S.L.S. 2016. Morphological and molecular data reveal the cryptic diversity among populations of Aegla paulensis (Decapoda, Anomura, Aeglidae), with descriptions of four new species and comments on dispersal routes and conservation status. Zootaxa, 4193: 1-48.

Nicolet, H. 1849. Crustaceos. p. 198-201. In: Gay, C. (ed), Historia Física y politica de Chile, 3. Zoologia. Paris, Maulde Y Renou.

Pérez-Losada, M.; Jara, C.G.; Bond-Buckup, G. and Crandall, K.A. 2002. Phylogenetic relationships among the species of Aegla (Anomura: Aeglidae) freshwater crabs from Chile. Journal of Crustacean Biology, 22: 304-313

Pérez-Losada, M.; Jara, C.G.; Bond-Buckup, G. and Crandall, K.A. 2004. Molecular systematics and biogeography of the southern South American freshwater "crabs" Aegla (Decapoda: 
Anomura: Aeglidae) using multiple heuristic tree search approaches. Systematic Biology, 53: 767-780.

Posada, D. 2009. Selection of models of DNA evolution with JModelTest. Methods in Molecular Biology, 537: 93-112.

Santos, S.; Bond-Buckup, G.; Gonçalves, A.S.; BartholomeiSantos, M.L.; Buckup, L. and Jara, C.G. 2017. Diversity and conservation status of Aegla spp (Anomura, Aeglidae): an update. Nauplius, 25: e2017011.

Schmitt, W.L. 1942. The species of Aegla, endemic South American freshwater crustaceans. Proceedings of the United States National Museum, 91:431-520.
Stamatakis, A.; Hoover, P. and Rougemont, J. 2008. A rapid bootstrap algorithm for the RAxML Web servers. Systematic Biology, 57: 758-771.

WoRMS (2018). Aegla Leach, 1820. Accessed at: http://www. marinespecies.org/aphia.php? $\mathrm{p}=$ taxdetailsandid $=366970$ on 2018-07-01.

Xu, Y.; Pérez-Losada, M.; Jara, C.G. and Crandall, K.A. 2009. Pleistocene glaciation leaves deep signature on the freshwater crab Aegla alacalufi in Chilean Patagonia. Molecular Ecology, 18: 904-918. 